\title{
An Analytical Study of Apple Marketing Channels in Himachal Pradesh, India
}

\author{
Rashmi Chaudhary*, Yasmin Janjhua, Piyush Mehta and Tushar Verma
}

Dept. of Business Management, College of Horticulture, Dr Y. S. Parmar University of Horticulture and Forestry, Nauni, Solan, Himachal Pradesh (173 230), India

\section{Article History}

Manuscript No. AR1546

Received in $25^{\text {th }}$ February, 2016

Received in revised form $16^{\text {th }}$ March, 2016

Accepted in final form $4^{\text {th }}$ April, 2016

\section{Correspondence to}

"E-mail: rashmihpu@gmail.com

\section{Keywords}

Apple marketing channels, market intermediaries, apple marketing problems

\begin{abstract}
This study examined the factors influencing choice of different marketing channels by the apple orchardists. Further, the study aimed to find out their common marketing problems. Present study is based on primary data collected from a randomly selected sample of 110 apple orchardists in Jubbal Tehsil of District Shimla in Himachal Pradesh through a detailed and exhaustive questionnaire prepared by the researchers after reviewing the previous studies. The results indicate that pre-harvest contractors, private procurement companies, commission agents and local buyers are the predominant intermediaries of apple marketing channels in Himachal Pradesh. Findings of the study show that receipt of timely payments and lack of marketing knowledge are the factors which influence the orchardists to choose commission agents and local buyers for selling their produce whereas pre-harvest contractors and private procurement companies are mainly preferred for avoiding risk and labour problems. Empirical evidences suggest that growers are facing common marketing problem of inadequate labour and transportation, improper grading and packaging, bad condition of link roads, inadequate storage facility and absence of market information. It is suggested that the existing overall marketing channels should be updated by reducing number of intermediaries which would eventually reduce the gap between the unit income of the farmers and the market price. It is further suggested that orchardists should make their cooperative societies for remunerative returns of their produce through collective selling and direct marketing. There is a need to encourage cold storage facilities and co-operative marketing system for safe storage, quick transportation and better marketing.
\end{abstract}

\section{Introduction}

Apples are one of the most widely produced fruits in the world (Basannagari and Kala, 2013). India is ranked as the sixth largest world's Apple producing country. Cultivation of apples reaps big commercial benefits as the fruit remains in demand for most part of the year (Chauhan, 2014). Apple constitutes about 89 percentage of the total fruit production in Himachal Pradesh and during 2013-2014 (up to December 2014), 7.38 lakh tonnes of apple were produced (National Horticulture Board 2014). Marketing channels can be viewed as sets of interdependent organizations involved in the process of making a product or service available for consumption or use (Stern et al., 1999). Marketing channel comprises of various marketing functionaries that are engaged in distribution of produce from producer to the consumer. Effective apple marketing channels can lead to better revenues for the producers and better quality fruit for the consumers. Marketing of horticultural crops is affected by inadequate local markets, poor pricing system, lack of local markets to absorb supply, low produce prices, excess of intermediaries, and poor marketing institutions and coordination of farmers (Emana and Gebremedhin, 2007). It has been suggested that human and physical asset specificity (Barry, Sonka and Lajili, 1992; Sporleder, 1992; Westgren, 1994; Stigler, 1951; Macdonald, 1985), price instability, and product perishability (Sporleder, 1992) are considered to be positively associated with choice of marketing channel.

Apple is the predominant horticultural crop in the study area and also responsible for livelihood to many rural households. Recently it has been viewed that the orchardists of the study area have not reaped much commercial benefits despite of quantity and quality apple produce. However, the profits of marketing channel functionaries/intermediaries have comparatively increased. Efficient apple marketing channels which have minimal intermediaries and are profitable for the growers and consumers are very important for improving 
orchardists share in consumer rupee. Direct marketing in which producers sell directly to consumers has been reported to be a profitable channel for both growers and consumers and can be termed as an efficient marketing channel. In this backdrop, present study is an attempt to find out the existing marketing channels engaged in distribution of apples in the study area and try to find out the reasons for preference of a marketing channel by the orchardists. Analysing the factors influencing choice of any marketing channel will highlight the problems of the orchardists which are restricting them for choosing channel with lesser intermediaries like direct marketing. Considering the importance and complexities encountered in the marketing of apple produce, the present study will investigate the choice of marketing channels by the apple orchardists of the study area and factors influencing preference of different marketing channels. Moreover, the study will try to find out the common problems faced by orchardists in the marketing of apples.

\section{Materials and Methods}

Descriptive research design was undertaken for the present study considering its objectives. Jubbal Tehsil of District Shimla in Himachal Pradesh has been purposively selected for the present study as the district accounts for nearly $69 \%$ of total apple production in the state of which major share is produced in Jubbal Tehsil. Multistage random sampling technique was followed for collection of data. A complete list of villages (134) was obtained for the selected area, out of which eleven (11) villages were selected randomly and ultimate apple producers/ orchardists (110 in number) were chosen. Primary data was collected in the month of January, 2015 through a detailed and exhaustive questionnaire prepared by the researchers after reviewing the previous studies for knowing the perceptions of the orchardists. The questionnaire was based on five point likert type statements (5-strongly agree, 4-agree, 3-neither agree nor disagree, 2-disagree and 1-strongly disagree). Mathematical and statistical analysis was carried out using percentage, mean and standard deviation. Higher mean values reflect agreement for the statement and standard deviation shows the deviation of value from average.

\section{Results and Discussion}

Marketing channels engaged in distribution of apples from producer to consumers prevalent in the study area are presented in Table 1. Survey results put forth that small orchardists sell their crop at flowering stage to pre-harvest contractors who organize plant protection practices, picking and packaging of fruits whereas medium and large orchardists prefer to market their produce through commission agents. Direct marketing which is most appropriate and much remunerative is very uncommon channel of marketing for apples in Himachal Pradesh owing to the reasons like lack of marketing knowledge, difficulty in contacting the consumers directly, small farm

\begin{tabular}{lc}
\hline Table 1: Predominant apple marketing channels in the study area \\
\hline Channel (1) & $\begin{array}{c}\text { Producer- Pre-harvest Contractors- } \\
\text { Wholesalers- Retailers- Consumers }\end{array}$ \\
Channel (2) & $\begin{array}{r}\text { Producer- Commission agents- Wholesalers- } \\
\text { Retailers- Consumers }\end{array}$ \\
Channel (3) & $\begin{array}{r}\text { Producer- Local buyers- Wholesalers- } \\
\text { Retailers- Consumers }\end{array}$ \\
Channel (4) & $\begin{array}{c}\text { Producer- Private Procurement Companies- } \\
\text { Retailers- Consumers }\end{array}$ \\
\hline
\end{tabular}

size and small production and lack of institutional measures in this regard.

Preference of the orchardists of the study area for different marketing channels has been presented in Table 2. However, substantial percentage of sampled orchardists prefers more

Table 2: Percentage analysis of marketing channels selected by apple orchardists

\begin{tabular}{lccc}
\hline Marketing channel & Frequency $(\mathrm{N})$ & $\%$ & $\%$ of cases \\
Channel (1) & 35.0 & 20.2 & 31.8 \\
Channel (2) & 66.0 & 38.2 & 60.0 \\
Channel (3) & 50.0 & 28.9 & 45.5 \\
Channel (4) & 22.0 & 12.7 & 20.0 \\
Total & 173.0 & 100.0 & 157.3 \\
\hline
\end{tabular}

(Source: Field survey, 2015)

than one channel to sell the apple produce. A perusal of the data has indicated that commission agent $(60 \%)$ and local buyers (45.5\%) are most commonly used marketing channel which reflects their comparative effectiveness. Nevertheless, pre-harvest contractors $(31.8 \%)$ and private procurement companies (20\%) are also preferred by some of the orchardists.

A profitable marketing channel for growers is a prerequisite for ensuring fair returns to the farmers for their efforts. The economic efficiency of the marketing channel is generally measured in terms of the price-spread of an agricultural commodity. Table 3 presents the mean analysis of some selected factors affecting choice of apple marketing channel by the orchardists of the study area. The findings provide basis to infer that each channel choice has a specificity of reasons behind it. The results show that orchardists are preferring pre-harvest contractors for avoiding risk $(\mathrm{M}=4.29)$ and labour problem $(M=4.17)$ associated with marketing of apples. Apple growers also prefer pre-harvest contractors owing to the reason that they make timely payments $(\mathrm{M}=3.94)$. Data reveals that study area is facing problem of transportation $(\mathrm{M}=3.91)$ of apple due to which orchardists sell their produce to pre-harvest contractors. All the factors have obtained more than average mean value indicating the problems faced by the orchardists 


\begin{tabular}{|c|c|c|c|c|c|c|c|c|}
\hline \multirow{2}{*}{$\stackrel{\text { Marketing channels }}{\longrightarrow}$} & \multicolumn{2}{|c|}{ Channel (1) } & \multicolumn{2}{|c|}{ Channel (2) } & \multicolumn{2}{|c|}{ Channel (3) } & \multicolumn{2}{|c|}{ Channel (4) } \\
\hline & $\begin{array}{l}\text { Mean } \\
\text { (M) }\end{array}$ & $\begin{array}{l}\text { Standard } \\
\text { deviation }\end{array}$ & $\begin{array}{c}\text { Mean } \\
(\mathrm{M})\end{array}$ & $\begin{array}{l}\text { Standard } \\
\text { deviation }\end{array}$ & $\begin{array}{l}\text { Mean } \\
(\mathrm{M})\end{array}$ & $\begin{array}{l}\text { Standard } \\
\text { deviation }\end{array}$ & Mean (M) & $\begin{array}{l}\text { Standard } \\
\text { deviation }\end{array}$ \\
\hline Avoid risk & 4.29 & 0.82 & 2.33 & 1.19 & 2.34 & 1.04 & 3.13 & 1.30 \\
\hline Avoid labour problem & 4.17 & 0.89 & 1.88 & 1.00 & 3.61 & 1.07 & 4.09 & 0.86 \\
\hline Lack of marketing knowledge & 3.37 & 0.87 & 3.40 & 0.813 & 3.88 & 1.03 & 3.18 & 0.85 \\
\hline Avoid transportation problem & 3.91 & 0.70 & 3.00 & 1.36 & 3.96 & 0.81 & 3.94 & 0.82 \\
\hline Timely payments received & 3.94 & 0.90 & 3.81 & 0.76 & 3.92 & 0.83 & 3.59 & 0.79 \\
\hline Advance payments & 3.69 & 1.02 & 3.79 & 0.95 & 2.13 & 1.21 & 3.29 & 1.35 \\
\hline Busy in other farm operation & 3.77 & 0.97 & 1.91 & 1.05 & 4.37 & 0.80 & 3.73 & 0.70 \\
\hline Avoid certain sundry expenses & 3.66 & 0.76 & 3.57 & 1.06 & 3.57 & 1.061 & 3.45 & 0.59 \\
\hline Provide better rates & 3.77 & 1.08 & 3.82 & 0.69 & 3.81 & 0.763 & 3.55 & 0.06 \\
\hline Market regulated prices & 3.40 & 0.81 & 3.66 & 0.72 & 1.91 & 1.05 & 2.26 & 1.09 \\
\hline
\end{tabular}

(Source: Field survey, 2015)

and the usefulness of selling apple produce through pre-harvest contractors. Commission agents are preferred as a marketing channel as they provide better rates $(\mathrm{M}=3.82)$ and the prices offered by them are market regulated $(\mathrm{M}=3.66)$. Further it is noticed that timely $(\mathrm{M}=3.81)$ and advance payments $(\mathrm{M}=3.79)$ are also the factors contributing in selection of commission agents as a marketing channel. It can be inferred that local buyers are preferred as the apple growers are busy in other farm operation $(\mathrm{M}=4.37)$ and also for avoiding transportation problem $(\mathrm{M}=3.96)$. Further avoiding risk, advance payments and market regulated prices have been found to score minimum value i.e. $(\mathrm{M}=2.34),(\mathrm{M}=2.13)$ and $(\mathrm{M}=1.91)$ respectively. Further timely payments and lack of marketing knowledge has mean value of $(\mathrm{M}=3.92)$ and $(\mathrm{M}=3.88)$ respectively in case of local buyer marketing channel. The findings depict that labour problem is highly responsible for selling produce to private procurement company with mean score $(\mathrm{M}=4.09)$. Further lack of marketing knowledge $(\mathrm{M}=3.18)$, avoiding risk $(\mathrm{M}=3.13)$ and market regulated prices $(\mathrm{M}=2.26)$ have scored minimum values. Based on the results of the table, it can be concluded that the two most preferred channels in the study area which are commission agents and local buyers are selected due to the reason of timely payments whereas pre-harvest contractors are selected for avoiding risks. However, private procurement companies are selected for avoiding labour and transportation problems. The findings provide basis to infer that each channel choice has a specificity of reasons behind it connoting importance and performance of all the apple marketing channels. Further, it is suggested that the existing overall marketing channels should be updated by reducing number of intermediaries which would eventually reduce the gap between the unit income of the farmers and the market price.

Marketing of Apples are confronted with numerous problems and constraints due to their highly perishable nature and presence of many middleman. Thus, for encouraging the efficient marketing of the crop, various problems and constraints in their marketing need to be identified. Table 4 demonstrates mean analysis of problems faced while marketing the apple by orchardists. It is concluded that labour and transportation problems have obtained maximum mean values i.e. $(M=4.48)$ and $(M=4.22)$ respectively connoting the adversity of the problems. The main problems reported by the orchardists of the study area regarding the transportation were

\begin{tabular}{lcc}
\hline \multicolumn{3}{l}{ Table 4: Common apple marketing problems } \\
\hline Problems & Mean $(\mathrm{M})$ & Standard deviation \\
\hline Labour & 4.48 & 0.55 \\
Grading & 3.69 & 1.09 \\
Packaging & 3.60 & 1.09 \\
Storage & 4.08 & 0.81 \\
Transportation & 4.22 & 0.78 \\
Marketing intelligence & 3.45 & 0.87 \\
Mal practices & 3.06 & 1.04 \\
Apathy of cooperative & 3.45 & 1.03 \\
agencies & & \\
\hline
\end{tabular}

(Source: Field survey, 2015)

inadequate availability of trucks at proper time. Moreover, transporters raise the rates of carriage per box to Delhi and other markets during the peak apple producing seasons. Insufficient Storage $(M=4.08)$ and grading $(M=3.69)$ facilities, 
poor market intelligence $(M=3.45)$ were also identified as the important problems confronted during marketing of apples in the study area. Market malpractices, such as multiplicity of charges and unfair bidding/auctioning were also reported as main problems in apple marketing in the study area. There is a need to encourage cold storage facilities and co-operative marketing system for safe storage, quick transportation and better apple marketing. Therefore, more computerized grading and packaging facilities should be provided to the apple growers. There is a need to encourage cold storage facilities and co-operative marketing system for safe storage, quick transportation and better marketing as emphasized by Kumar (1991). Moreover, the Government with joint efforts of growers should work towards the establishment of cold storage in the study area. Refrigerated transport facilities are needed to transport products to distant/terminal markets. The railway authorities may provide an adequate number of insulated and refrigerated Railway wagons for more efficient and safe carriage of delicate high-value products to the far off areas. Therefore more computerized grading and packaging facilities should be provided to the apple growers.

\section{Conclusion}

The diversity of marketing intermediaries and channels suggest that selection of a marketing channel depends on a number of considerations. Orchardists prefer pre-harvest contractors for avoiding risk and labour problem associated with marketing of apples however commission agents are preferred as a marketing channel as they provide better rates and the prices offered by them are market regulated. It is found that apple growers of the study area are facing adverse labour, transportation, storage, grading and packaging problems.

\section{Further Research}

It is hoped that present study will stimulate further research in the field of apple marketing channels. Present study have examined selected factors for choice of marketing channel but a more exhaustive study should be conducted to reveal that why pre-harvest contractors and commission agents are preferred by most of growers. Further it is also desirable to know why most of the small and marginal growers sell their produce in villages and adjoining towns.

\section{References}

Basannagari, B., Kala, P., 2013. Climate change and apple farming in Indian Himalayas: A study of local perceptions and responses 8(10). Available from http://journals.plos. org/plosone/article?id=10.1371/journal.pone.0077976.

Barry P., Sonka, S., Lajili, K., 1992. Vertical coordination, financial structure and the changing theory of the firm. American Journal of Agricultural Economics 72, 12191225 .

Chauhan, A., 2014. A study on marketing of apples in Shimla District of Himachal Pradesh, Report UHF, Nauni (Unpublished).

Emana, B., Gebremedhin, H., 2007. Constraints and opportunities of horticultural production and marketing in eastern Ethiopia. www.everythingharar.com.Accessed in March 2015.

Kumar, R., 1991, Marketing of vegetables in Solan district of Himachal Pradesh, An M.Sc. Dissertation, Himachal Pradesh Krishi Vishvidalaya Palampur, in press.

Macdonald, J.M., 1985. Market exchange or vertical integration an empirical analysis. The Review of Economics and Statistics 67, 327-31.

Mehta, K., Jindal, K.K., 2003. Overview analysis of apple crop problems in Himalayas and available technology options in apple farming and livelihood in Himalayas, 43-59.

Mishra, S., 2013. A GAIN report on apple product brief, Global Agricultural Information Network. Report No. IN3069, New Delhi, 3-5.

Stigler, G., 1951. The division of labour is limited by the extent of the market. Journal of Political Economics 59, 185-193.

Sporleder, T., 1992. Managerial economics of vertically coordinated agricultural firms. American Journal of Agriculture Economics 74, 1226-1231.

Stern, L.W., Ansary, A., Coughlan, A., 1999. Marketing Channels. Prentice Hall of India, New Delhi, 1.

Westgren R., 1994, Case studies of market co-ordination in the poultry industries. Canadian Journal of Agricultural Economics 42, 565-575. 